\title{
1. War is a racket: In memory of Smedley Butler
}

\subsection{DEFINITION OF WAR}

War is a state of armed conflict between states, governments, societies and factions. According to the Oxford English Dictionary, war is defined as "a state of armed conflict between different countries or different groups within a country"; "a state of competition or hostility between different people or groups"; and "a sustained campaign against an undesirable situation or activity". A war is typically fought by a country (or a group of countries) against an opposing country (or a group of countries) to accomplish an objective through the use of force. Wars can also be fought within a country in the form of civil or revolutionary war. The scholarly study of war is known as "polemology", which is derived from the Greek polemos, meaning "war", and -logy, meaning "the study of".

War has been part of human history for thousands of years. It has become increasingly destructive as a result of industrialisation and technological progress. It is generally characterised by extreme violence, aggression, destruction and mortality. Total war is not restricted to purely legitimate military targets, typically resulting in massive (but unnecessary) civilian or other non-combatant suffering and casualties. Wars may be fought by using irregular military forces - that is, non-standard military personnel that are distinct from a country's regular armed forces. An informal paramilitary group is a semi-militarised force whose organisational structure, tactics, training, sub-culture and (often) function are similar to those of a professional military, even though it is not regarded as part of a state's formal armed forces.

Informal forces include mercenaries, insurgents and militias. Mercenaries are not part of a regular army or other governmental military force, but they are hired to take part in an armed conflict. Insurgents participate in a rebellion against an authority that is recognised as such by the United Nations (UN) but they are not recognised as belligerents (lawful combatants). A militia is generally an army or some other fighting organisation of non-professional soldiers, ordinary citizens or subjects of a state who can be called upon for military 
service when needed (as opposed to a professional force of regular, full-time military personnel).

The concept of "war aims" refers to the "desired territorial, economic, military or other benefits expected following successful conclusion of a war" (Fried, 2014). These aims are interlinked in the sense that territorial gains are also economic gains. Military gains typically imply economic gains, and other benefits invariably involve economic benefits. Welch (1995) distinguishes between tangible gains (such as arms, wealth, resources and territory) and intangible gains (such as credibility and reputation). However, credibility and reputation may lead to gains even without further war, as the threat of war would suffice. Explicit war aims may involve published policy decisions whereas implicit aims can take the form of minutes of discussion, memoranda and instructions. Explicit war aims, as declared, may not represent the true implicit aims - this is a characteristic of almost every war of aggression. War aims may be positive, in the sense of having tangible outcomes, whereas negative aims are intended to forestall or prevent undesired outcomes (see, for example, Fried, 2015).

The morality of war has been the subject of debate for thousands of years. The just war theory, which was foundational in the creation of the UN and the stipulation of international law on the legitimacy of war, seeks to provide conditions under which war is justified and to specify how war should be conducted. The two main principles are proportionality (how much force is necessary) and discrimination (determining legitimate targets in a war). Discrimination means separation between combatants, who can be killed legitimately, and non-combatants who should not be killed or harmed.

Several criteria govern the conduct of a just war. It can be waged only as a last resort, in the sense that all non-violent options must be exhausted before the use of force can be justified. A war is just only if it is waged by a legitimate authority, and even just causes cannot be served by actions taken by individuals or groups who do not constitute an authority sanctioned by whatever the society and outsiders deem legitimate. A just war can be fought only to redress injustice of some sort. For example, self-defence against an armed attack is always considered to be a just cause. A war is just only if it is fought with a reasonable chance of success, which means that the death and injury incurred by fighting for a hopeless cause are not morally justifiable. The ultimate objective of a just war is to re-establish peace, or at least that the peace established at the end of hostilities must be preferable to the peace that would prevail without war. The violence used in a just war must be proportional to the suffering that causes the war in the first place. The weapons used in a just war must discriminate between combatants and non-combatants, and every effort must be taken to avoid the killing of civilians. 
The ideas governing the conduct of a just war are admirable but in reality wars of aggression are portrayed as just wars that are fought to correct injustice. The aggressor is portrayed as being a victim while the target becomes a "terrorist". In reality, the loser is put on a trial for war crimes but the victor gets away with murder. Even fascism, racism and imperialism put a case for just war. Racists see violence as the means for establishing a master race. For social Darwinism, violence is sometimes necessary to weed the unfit from society, so that civilisation can flourish. For fascists and imperialists, the ends justify the means.

\subsection{HISTORY OF WAR}

In 1964 a team led by Fred Wendorf discovered the 14,000-year-old Mesolithic cemetery (also called Jebel Sahaba and Site 117), which is a prehistoric cemetery site in the Nile Valley (now submerged in Lake Nasser, southern Egypt). No less than 45 per cent of the skeletons found in the cemetery displayed signs of violent death, from which one can only assume that they met their end in a savage battle (see, for example, Keeley, 1996). The use of military force became a more frequent worldwide phenomenon with the invention of the state about 5000 years ago as a political organisation with a centralised government that maintains a monopoly on the legitimate use of force within a certain geographical territory. According to Henderson (2010), 14,500 wars took place between $3500 \mathrm{BC}$ and the late 20th century, claiming 3.5 billion lives and leaving only 300 years of peace. Since the late 18th century, Western Europe has witnessed more than 150 military conflicts involving about 600 battles.

Absolute numbers of death may not give the right picture of the severity of losses, in which case it is better to use losses as a proportion of prewar population. In this sense, the most destructive war in modern history may have been the Paraguayan War, also known as the "War of the Triple Alliance" and the "Great War in Paraguay". That war was fought from 1864 to 1870 between Paraguay and the triple alliance of Argentina, the Empire of Brazil and Uruguay. The war devastated Paraguay, as almost 70 per cent of its adult male population died, and it was forced to cede territory to Argentina and Brazil. During the Thirty Years' War in Europe, the population of the Holy Roman Empire was reduced by $15-40$ per cent.

Death could happen on a massive scale off the battlefield. For instance, of the 9 million people who were on the territory of Byelorussia in 1941, some 1.6 million were killed by the Germans in action away from battlefields (Snyder, 2010). Even after the end of hostilities, people die because of famine, large-scale displacement, deterioration of infrastructure and the ecosystem, declining social spending and the mistreatment of prisoners of war and civilians. Most of the civilian deaths resulting from the United States (US) invasion 
of Iraq occurred after George Bush's declaration of "mission accomplished", which supposedly marked the end of hostilities. Most wars have resulted in significant loss of life, along with the destruction of infrastructure and resources (which leads to famine, disease and death in the civilian population). Civilians in war zones may also be subject to war atrocities, such as genocide, while survivors may suffer the psychological after-effects of witnessing the destruction of war. War leads to forced migration, causing potentially large displacements of the population.

The negative effects even engulf the soldiers of the victors, and not only those who lose life or limb. With reference to World War II, Grossman (1996) found that after 60 days of continuous combat, 98 per cent of all surviving military personnel became psychiatric casualties as manifested by fatigue, confusion, hysteria, anxiety, obsession, compulsion and character disorders. With reference to the Vietnam War, Grossman found that anywhere from 18 to 54 per cent of the veterans suffered from post-traumatic stress disorder, which is a mental disorder that can develop after a person is exposed to a traumatic event such as warfare.

In terms of the number of deaths, the most devastating wars include World War II (1939-45), the Mongol Conquests (13th century), the Taiping Rebellion (1850-64), the An Lushan Rebellion (755-63), the Qing conquest of Ming (1616-62), the Second Sino-Japanese War (1937-45), the Conquests of Timor (1370-1405) and World War I (1914-18). Figure 1.1 shows the cumulative death toll of selected wars, falling between the Italian wars of 1494-1559 (that took 346,000 lives) and the Iraqi civil war (the campaign against ISIS) that started in 2014 and took 75,000 lives. We can readily observe six big jumps, the biggest of which is associated with World War II, which involved more than 100 million people from over 30 countries and claimed at least 69 million lives. Most of the victims were civilians in the Soviet Union and China (some estimates put the death toll as high as 80 million).

The Mongol conquests of the 13th century claimed 60 million lives. It is believed that the Mongol expeditions may have brought with them the bubonic plague, spreading it across much of Asia and Europe and leading to the massive loss of life in the Black Death of the 14th century. The Taiping Rebellion, also known as the "Taiping Civil War" or the "Taiping Revolution", claimed 40 million lives. It was a massive rebellion or total civil war that was waged in China from 1850 to 1864 . The An Lushan Rebellion against the Tang dynasty of China, which began in December 755, claimed 36 million lives. Another Chinese war that cost 25 million lives was the Qing dynasty conquest of the Ming dynasty. The Second Sino-Japanese War, lasting between July 1937 and September 1945, took 20 million lives. The conquests of Timor in the 12th century lasted 35 years and claimed 20 million lives. Last, but not least, the first mechanised war (World War I) cost 19 million lives and a total 


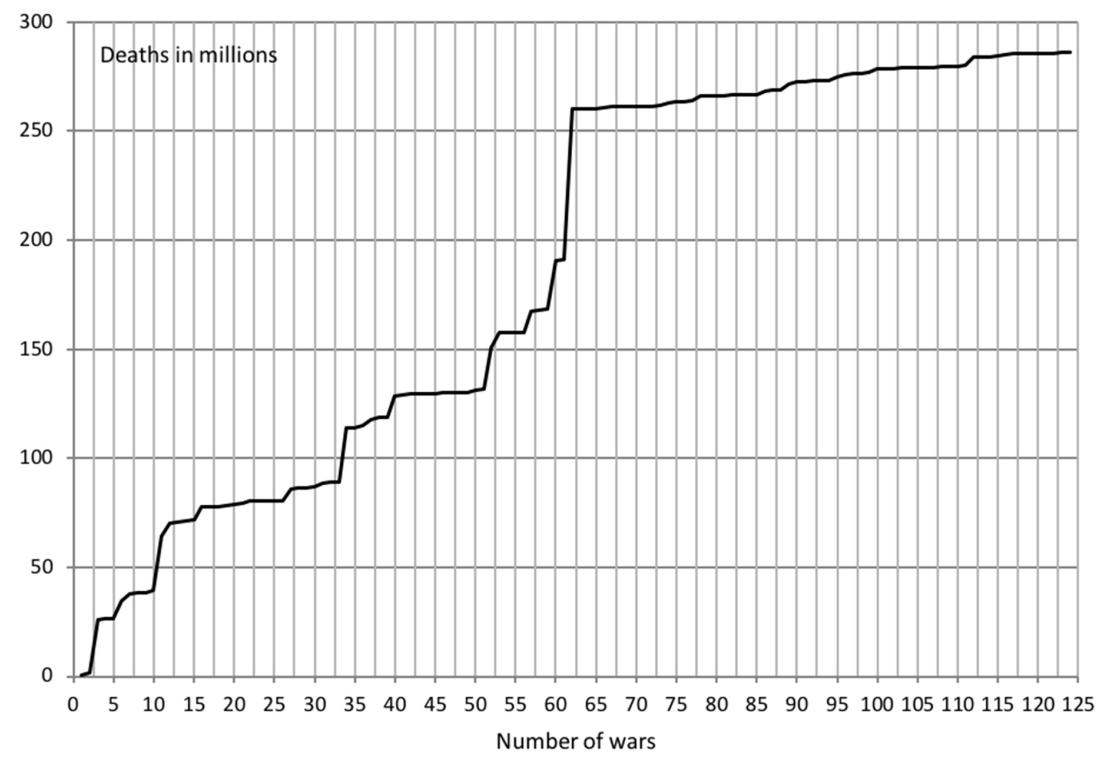

Figure 1.1 Cumulative deaths of major wars since 1499

casualty figure of 40 million, even more if genocides and the 1918 influenza pandemic are taken into account.

Wars can be classified under several headings. A war of aggression, also called a war of conquest, is a military conflict waged without the justification of self-defence, usually for territorial gain and subjugation. This kind of war, typically associated with imperialism, is motivated by economic gains, and it is invariably launched by a powerful country against a weak one. The Spanish conquest of the Inca Empire was mainly motivated by the insatiable desire to accumulate gold. The French conquest of Algeria was intended to find new territory where the French could live as masters of the indigenous people. These wars are typically justified and portrayed as just wars. The Anglo-American invasion of Iraq was justified in terms of revenge for the 9/11 attacks (which Iraq had nothing to do with) and the objective of destroying Iraq's weapons of mass destruction (WMDs), which did not exist.

Imperialist wars as defined here are wars between imperialist powers over territory and economic gains. Perhaps the best example is World War I, which was fought by the big empires at that time to redistribute colonies, although it was justified by other means. Before World War I, several European countries had made competing imperialistic claims in Africa and parts of Asia, making them points of contention. Because of the raw materials these 
areas could provide, tensions ran high around which country had the right to exploit them. Intensifying competition and the desire for greater empires led to an escalation in confrontation that helped push the world into World War I. The Anglo-Spanish War of 1585-1604 was supposed to have started for religious reasons, but the motivation was economic: the Spanish did not like how the British conducted trade with their colonies in the West Indies. The Second Boer War (1899-1902) was caused by the discovery of gold in the Witwatersrand region of the South African Republic, which prompted a desire for Britain, already in control of the Cape Colony and Natal, to incorporate the Boer republics into a southern African federation under its control.

Wars of independence and defensive wars (or revolutionary war) come in reaction to wars of aggression. The Venezuelan War of Independence (1810-23) was fought against Spanish occupation, starting with the declaration in July 1811 of independence by seven of the ten provinces of the Captaincy General of Venezuela. The Cuban War of Independence (1895-98) was also fought against Spanish imperialism, but it ended with the involvement of American imperialism. The Algerian War of Independence (1954-62) was fought against French imperialism in reaction to the failure of France to fulfil promises of greater self-rule in Algeria after World War II.

A civil war is simply a war between the citizens of the same country. The aim of one side may be to take control of the country or a region, to achieve independence for a region, or to force changes in government policies. Civil wars may be caused by greed or grievance - in other words, economic gains or identity. The American Civil War (1861-65) involved a big economic factor, as conflict arose between the industrial north and the farming south. The Spanish Civil War (1936-39) was caused by many factors, including major socio-economic problems such as poverty and inequality. However, one of the main causes was all sides' failure to compromise and to respect the rights and opinions of others. Civil wars invariably involve an economic dimension such as the control of resources.

\subsection{THE BUTLER PROPOSITION}

In 1935 retired US Marine Major General Smedley Butler published a book, or rather an essay, in which he characterised war as a "racket" (Butler, 1935). In this essay he identified war profiteers, with particular reference to World War I, and specified who paid the bills for war. He further suggested how to smash the racket and concluded by raising the slogan "to hell with war". This is rather strange, coming from a general, since generals typically benefit from war - they get the glory while sending soldiers to death, and some of them end up being presidents or at least highly paid executives in the military industry. On this issue, Butler noted that the military are not for disarmament because 
"no admiral wants to be without a ship" and "no general wants to be without a command".

Butler described a racket as "something that is not what it seems to the majority of the people" and that "only a small 'inside' group knows what it is about". A racket, he argued, "is conducted for the benefit of the very few, at the expense of the very many". War is a racket because "out of war a few people make huge fortunes". He goes on to say the following: "War is a racket. It always has been. It is possibly the oldest, easily the most profitable, surely the most vicious. It is the only one international in scope. It is the only one in which the profits are reckoned in dollars and the losses in lives."

Butler estimated that at least 21,000 new millionaires and billionaires were made in the US during World War I, suggesting that this number represents only those who did not falsify their tax returns. None of them, he argued, shouldered a rifle, dug a trench, knew what it meant to go hungry in a rat-infested dug-out, spent sleepless, frightened nights ducking shells and shrapnel and machine gun. None of them, he wrote, parried a bayonet thrust of an enemy, wounded or killed in battle. Then he moved on to talk about the bill, which he described as "rendering a horrible accounting", involving "newly placed gravestones, mangled bodies, shattered minds, broken hearts and homes, economic instability, depression and all its attendant miseries, back-breaking taxation for generations and generations".

War is typically justified in the name of patriotism, democracy and similar ideals. Butler recognised the fact that soldiers were brain-washed before they were sent on a mission to die. This is what he wrote in this respect:

Beautiful ideals were painted for our boys who were sent out to die. This was the "war to end all wars". This was the "war to make the world safe for democracy". No one mentioned to them, as they marched away, that their going and their dying would mean huge war profits. No one told these American soldiers that they might be shot down by bullets made by their own brothers here. No one told them that the ships on which they were going to cross might be torpedoed by submarines built with United States patents. They were just told it was to be a "glorious adventure".

Butler proposed to put an end to the racket by conscripting the directors and executives of armament factories, munitions makers, shipbuilders, airplane builders and the manufacturers of all the other things that provide profit in wartime as well as bankers and speculators. Another step that is necessary to smash the war racket is "the limited plebiscite to determine whether a war should be declared", provided that it is not a plebiscite of all the voters but merely of those who would be called upon to do the fighting and dying. A third step, according to Butler, is to make certain that military forces are deployed for defence only. He suggested, for example, that the ships of the US navy should be specifically limited, by law, to within 200 miles of the US coastline. 
Woodrow Wilson was re-elected US president in 1916 on the platform that he had "kept us out of war" and on the implied promise that he would "keep us out of war". Butler wondered why Wilson asked Congress to declare war on Germany only five months later, but then he suggested a simple explanation: money. This is what the head of an allied commission told President Wilson:

There is no use kidding ourselves any longer. The cause of the allies is lost. We now owe you (American bankers, American munitions makers, American manufacturers, American speculators, American exporters) five or six billion dollars. If we lose (and without the help of the United States we must lose) we, England, France and Italy, cannot pay back this money ... and Germany won't. (Smedley Butler 1935.)

The US entered World War I, not because of the sinking of the Lusitania, but rather because industrialists and bankers stood to lose a lot, particularly if Germany had won the war. But then it does not matter who wins the war, as money can be made in any case. This is why Butler concluded his essay with the slogan "to hell with war". Butler's hypothesis therefore is that war is fought for economic reasons, for money. The wars that have taken place since his death have proven him right.

Dane (2015) follows Butler by concluding with the slogan "to hell with war". She extends Butler's analysis to the present time, by saying the following about a top war profiteer, Lockheed Martin:

Chief executive officer (CEO) Marillyn Hewson earned \$25.16 million in 2014. Of this total, $\$ 1.34$ million was base salary, $\$ 8.16$ million was stock awards, $\$ 5.98$ million was from incentive plan compensation, $\$ 9.41$ million was in pension earnings, and other compensation was $\$ 238,150 \ldots$ As you can see, many companies and individuals - including politicians - stand to profit greatly from perpetual war. And we, the taxpayers, are footing the bill.

She goes on to say the following:

Every hour, taxpayers in the United States are paying $\$ 312,500$ for cost of military action against ISIS. Every hour, taxpayers in the United States are paying \$10.17 million for cost of war in Afghanistan. Every hour, taxpayers in the United States are paying $\$ 365,297$ for cost of war in Iraq. Every hour, taxpayers in the United States are paying $\$ 10.54$ million for total cost of wars since 2001. Every hour, taxpayers in the United States are paying $\$ 8.43$ million for Homeland Security since 9/11. Every hour, taxpayers in the United States are paying $\$ 58$ million for the Department of Defense.

She notes that "the full costs of war cannot simply be measured in dollars" and that "it is impossible to place a monetary value on the tremendous loss of life (both military and civilian) caused by perpetual war". She refers to the 2356 US military deaths, 453 United Kingdom (UK) military deaths and 677 coali- 
tion military deaths in Afghanistan. She refers to the 4489 US military deaths and the 179 UK military deaths in Iraq. She refers to the 136,495-154,378 documented civilian deaths in Iraq (the real figures are multiples thereof). She refers to "an unusually high percentage of young veterans" who have died since returning home, many as a result of drug overdose, suicide and vehicle crashes. Needless to say, the Iraq and Afghanistan campaigns represent wars of aggression, even though the aggressors portray the incursions as just wars. Well, just wars are supposed to correct something gone wrong. Dane explains that in many ways, the people of Afghanistan and Iraq are worse off now than they were before the onslaught of the angels of death. As a result of the attempt to impose democracy by force (one of the declared objectives of the invaders), both countries are currently more authoritarian, more corrupt and more repressive than they were before.

\subsection{CONCLUDING REMARKS}

In his magnificent piece, War Is a Racket, Smedley Butler recognised two forms of war profiteering by the industrialists who supply war material and bankers who finance the warring parties. However, other forms of war profiteering can be identified as war is the ultimate enterprise. To start with, imperialism and wars of aggression are motivated by the desire to secure raw materials and markets for the industrialists. This is the essence of Lenin's thesis that imperialism is the highest state of capitalism. Profit can be generated by looting public assets in the invaded countries (examples are Iraq, the Belgian Congo and the territories conquered by Japanese imperialism). The Opium Wars were fought mainly to protect Britain's lucrative drug trade in China - they were fought for the benefit of drug dealers.

Bombs and rockets cost a lot of money - without war, the firms that produce bombs and rockets go out of business and their CEOs lose their bonuses. War is essential for the profitability of companies providing mercenaries such as Blackwater (now known as Academi) and companies providing services to the occupation forces such as Dick Cheney's KBR in Iraq. War provides financial benefits for the government officials and ruling cabals ordering wars of aggression. The Bushs benefited financially from the occupation then liberation of Kuwait, and so did King Leopold from Belgium's brutal occupation and exploitation of the Congo.

Wars fought for the purpose of regime change provide lucrative contracts if the mission is accomplished. This is what happened in the Chilean 9/11 in 1973, and this is the objective of attempts to topple Nicolas Maduro as imperialist countries gang up like a pack of rabies-stricken dogs to force a regime change in Venezuela. Occupied countries become good customers of the military and non-military suppliers of the country committing the aggression (for 
example, Iraq has been acquiring American military hardware on a massive scale since 2003). War allies convinced to join wars by the cheer leaders become customers of the military contractors in the cheer-leading country, and this is why Australia is as valued a customer of the American military industry as Saudi Arabia is. Last, but not least, war provides revenue for the state when its army acts like a mercenary force. The liberation of Kuwait involved payments in billions of dollars from Kuwait and Saudi Arabia to the US.

The argument put forward in this book is that wars are about money rather than the noble causes often claimed to be the true causes. War involves the transfer of wealth from taxpayers to war profiteers, from the defeated to the victors, from the victims to the aggressors and from the oppressed to the oppressors. Different kinds of war profiteering and war profiteers are discussed in Chapters 6,7 and 8. The argument that war is motivated by potential economic gains is valid particularly for the wars of aggression launched by powerful countries on weak ones. Only wars of liberation are not motivated by money, although liberation itself puts an end to exploitation by the aggressor. 